\title{
VIRTUALNO S GRADSKOM KNJIŽNICOM „IVAN GORAN KOVAČIĆ“ KARLOVAC - PROGRAMI ZA SVE UZRASTE
}

\author{
GOING VIRTUAL WITH THE PUBLIC LIBRARY \\ "IVAN GORAN KOVAČIĆ" KARLOVAC - \\ PROGRAMS FOR ALL AGES
}

\author{
Lidija Šajatović \\ Gradska knjižnica „Ivan Goran Kovačić““ \\ Karlovac \\ lidija@gkka.hr
}

UDK / UDC [027.022:004]: 616.2-

044.372(497.5 Karlovac)

Stručni rad / Professional paper

Primljeno / Received: 27. 11. 2020.

Prihvaćeno / Accepted: 8. 2. 2021.

\section{Sažetak}

Cilj. U radu su predstavljene online usluge Gradske knjižnice „Ivan Goran Kovačić“ Karlovac koje su omogućile učinkovitiji rad u uvjetima pandemije uzrokovane virusom SARS-CoV-2. Također su pobliže prikazani virtualni programi koji su se održavali ili se održavaju od ožujka 2020. godine do danas. Cilj je rada prikazati kako je omogućen nastavak produkcije knjižničnih programa u izvanrednim uvjetima, kao i predstaviti novi način poslovanja.

Metodologija. U prvom dijelu rada analiziran je teorijski okvir rada knjižnica na svjetskoj i nacionalnoj razini u okolnostima proglašene epidemije bolesti COVID-19. Drugi dio rada donosi detaljan pregled virtualnih usluga i programa Gradske knjižnice „Ivan Goran Kovačićc Karlovac za sve dobne uzraste, a koji uključuju književne susrete, kreativne radionice, predstavljanje online usluga knjižnice i edukaciju korisnika, kvizove, virtualne izložbe i preporuke za čitanje. Izneseni su rezultati ispitivanja zadovoljstva korisnika navedenim uslugama i programima.

Vjesnik bibliotekara Hrvatske 64, 1(2021), 175-199

ISSN 0507-1925 
Rezultati. Prikaz inovativnih programa i usluga osmišljenih u svrhu poticanja čitanja, razvijanja kreativnosti i usvajanja novih vještina u novonastalim okolnostima pokazuje kako Gradska knjižnica „Ivan Goran Kovačić“ Karlovac u svom radu kontinuirano nastoji redefinirati ulogu knjižnice u svjetlu nadolazećih promjena te svojim pristupom pridonosi razvoju lokalne zajednice.

Originalnost. Primjeri dobre prakse Gradske knjižnice „Ivan Goran Kovačić“ Karlovac naglašavaju važnost promjene načina rada kao i načina razmišljanja samih knjižničara u doba koronavirusa te mogu poslužiti kao primjer drugim knjižnicama.

Ključne riječi: Gradska knjižnica Karlovac, koronavirus, online usluge, virtualni programi

\begin{abstract}
Purpose. The paper presents the Public Library "Ivan Goran Kovačić" Karlovac online services, which enabled more efficient work in a pandemic circumstances caused by the COVID-19 virus. Virtual programs that have been held from March 2020 until today are also presented in more detail. The aim of this paper is to show possibility of continuing the production of library programs in exceptional circumstances as well as to present a new way of organizing library operations.
\end{abstract}

Approach. The first part of the paper analyzes the theoretical framework of the library work at the global and national level in the circumstances of the pandemic of the COVID-19 virus. The second part of the paper provides a detailed overview of the Public Library "Ivan Goran Kovačić" Karlovac virtual services and programs for all ages, which include literary meetings, creative workshops, presentation of online library services and user education, quizzes, virtual exhibitions, and reading recommendations. The results of the user satisfaction survey with the mentioned services and programs are also presented.

Results. The review of innovative programs and services designed to encourage reading, develop creativity and acquire new skills in the new circumstances shows how the Public Library "Ivan Goran Kovačić" Karlovac in its work continuously seeks to redefine the role of the library in light of upcoming changes and how its approach contributes to local community development.

Originality. The examples of good practice in the Public Library "Ivan Goran Kovačić" Karlovac emphasize the importance of changing the way of working as well as the way of thinking in the age of coronavirus and can serve as a model for other libraries.

Keywords: Coronavirus, Karlovac Public Library, online services, virtual programs 


\section{Uvod}

Odlika knjižnica, između ostalog, jest uspješan prijelaz iz transakcijskih ustanova u relacijske. Za razliku od, u prošlosti, obavljanja transakcija koje podrazumijevaju posudbu knjiga ili rješavanje upita, knjižnice su danas definirane međusobnim odnosima. ${ }^{1}$ Glavni je cilj knjižnica bio ispuniti korisnikovu potrebu za znanjem i obrazovanjem, dok u današnje vrijeme prostor knjižnica ima višestruku ulogu; služi kao prostor za održavanje radionica, tečajeva, sastanaka čitateljskih klubova, korištenje novih tehnologija, a knjižničari preuzimaju ulogu edukatora, savjetnika i moderatora. Knjižnice, u neku ruku, postaju domaćini. No, kako djelovati kada knjižnice prisilno izgube dragocjenu mogućnost „domaćinstva“? Kako zadržati postojeće odnose i stvarati nove kada izgubite mogućnost rada s korisnicima uživo? Knjižnice se, kao i mnogo puta dosad, moraju prilagoditi. U ovom slučaju, promjena je stigla neočekivano i preko noći.

Diljem svijeta knjižnice su bile prisiljene zatvoriti svoja vrata korisnicima te zaustaviti odvijanje postojećih aktivnosti kao i reorganizirati usluge. Knjižnice su se okrenule virtualnom svijetu.

Preduvjet rada u knjižnici posjedovanje je osnovne digitalne pismenosti i vještina. Svijet informacijske tehnologije mijenja se neumoljivom brzinom, a ravnatelji knjižnica i knjižničari moraju pronaći jednostavan način kako bi se informirali i ostali u toku, kao i implementirati nove dostupne tehnologije u jedinstveno knjižnično poslovanje. ${ }^{2}$ Knjižnice su oduvijek imale ključnu ulogu u diseminaciji informacija, a bez informacijske tehnologije i primjene praktičnih znanja u svakodnevnom radu, sav trud prikupljanja i pohrane informacija propao bi.

Gradska knjižnica „Ivan Goran Kovačić“ Karlovac jedna je od pet najvećih knjižnica u Republici Hrvatskoj te najstarija ustanova u kulturi u Gradu Karlovcu i Karlovačkoj županiji. Dugogodišnja tradicija organizacije kvalitetnih programa i usluga za korisnike i posjetitelje knjižnice, kao i otvorenost svim građanima lokalne zajednice samo je dio misije njezina poslovanja. Programi su organizirani za sve uzraste i skupine - djecu i mlade, odrasle, umirovljenike, osobe s intelektualnim teškoćama i migrante. Istodobno, u sklopu knjižnice djeluje i Središnja knjižnica Slovenaca koja je osnovana 1993. godine. Knjižnica za mlade dislocirani je odjel otvoren 2003. godine, a Knjižnična stanica Švarča djeluje od 2016. godine. U ožujku 2020. godine poslovanje knjižnice promijenilo se do daljnjega. Određeni programi i aktivnosti privremeno su obustavljeni, a poticao se razvoj novih usluga od kojih su neke postale trajno primjenjive. Novonastala situacija uzrokovana pojavom koronavirusa promijenila je ne samo način poslovanja knjižnica već i

1 Usp. Modern libraries: moving from a transactional to a relational library. // Princh. [citirano: 2020-11-24]. Dostupno na: https://princh.com/modern-libraries-from-a-transactional-to-a-relational-library/\#.W4-eL-gzZEZ\%C5\%BE.

2 Usp. Burke, J. Neal-Schuman library technology companion: a basic guide for library staff. Chicago: Neal-Schuman, 2016. Str. ix. 
način razmišljanja knjižničara, a primjeri dobre prakse diljem svijeta pokazuju da se knjižničarska struka prilagodila izazovima.

\section{Rad knjižnica u svijetu u okolnostima proglašene epidemije bolesti COVID-19}

IFLA navodi kako su knjižnice diljem svijeta na pojavu koronavirusa reagirale različito:

- Poslovanje knjižnica više-manje uobičajeno je, kao prije pojave koronavirusa. U takvim slučajevima preporučuju se osnovne mjere higijene (osigurani su dezinficijensi za korisnike i zaposlenike knjižnica, održava se čistoća radnih površina, računala i igračaka, dostupne su mrežne stranice s korisnim poveznicama, kao i promicanje medijske pismenosti).

- Rad s ponekim ograničenjima. Razmatra se održavanje programa poput pričaonica i radionica koje uključuju rizične skupine korisnika, razmišlja se o možebitnom zatvaranju čitaonica, obavljaju se pripreme za veća ograničenja i rad od kuće.

- Knjižnične usluge svedene su na najmanju moguću mjeru. Omogućena je samo posudba knjiga na središnjem pultu knjižnice, putem knjigomata ili drive-ina, uvodi se karantena razduženih knjiga, implementiraju usluge na daljinu, poput $e$-učenja ili $e$-posudbe te se uvodi rad od kuće.

- Potpuno zatvaranje knjižnica. U gradovima i područjima gdje su epidemiološke mjere najstrože, knjižnice su prisilno ili svojevoljno zatvorile vrata kako bi zaštitile korisnike i osoblje knjižnica. Knjižničari rade od kuće, a u slučaju dolaska na posao, poštuje se fizička udaljenost. Promoviraju se online usluge, organiziraju pričaonice poštujući autorska prava, korisnicima se opraštaju zakasnine i povećava se broj $e$-knjiga koje korisnici mogu posuditi.

- Pripreme za ponovno otvaranje. U procesu ponovnog otvaranja, knjižnice posebnu pozornost moraju posvetiti sigurnosti; ograničava se broj ljudi koji istodobno smiju boraviti u prostoru knjižnice, redovito se dezinficira prostor i radne površine, korisnike se potiče na praćenje virtualnih programa i online usluga, jasno se definiraju nova pravila ponašanja za korisnike. ${ }^{3}$

Prikladna je izjava Darcy Brixey, voditeljice knjižnice sa sjedištem u Seattleu koja ima dvadesetogodišnje iskustvo rada u narodnim i sveučilišnim knjižnicama. Ona zaključuje da su knjižnice jedno od rijetkih mjesta na koje možete otići, a da se

3 Usp. IFLA. COVID-19 and the global library field. 2020. [citirano: 2020-11-06]. Dostupno na: https://www.ifla.org/covid-19-and-libraries. 
od vas ne očekuje da morate nešto i kupiti. ${ }^{4}$ Riječ je o nekim osnovnim potrebama, poput činjenice da negdje možete biti na suhom i toplom ili pak koristiti se toaletom. To se pojavom korone izgubilo, čitaonice u knjižnicama mahom ne rade, preporučuje se što kraće zadržavanje u prostorijama knjižnice, prakticira se fizička udaljenost. Činjenica je da su knjižnice ipak bile i ostale više od knjiga; multifunkcionalni prostori koji služe i kao svojevrsna skloništa za socijalno ugrožene građane.

U travnju 2020. godine, u Sjedinjenim Američkim Državama upravo se knjižničarska zajednica najviše pobunila protiv izdanog priopćenja s preporukama za postupno otvaranje lokalnih zajednica, a samim time i javnih ustanova. Naime, znanstvenici s uglednog Sveučilišta Johns Hopkins i njihovog Istraživačkog centra za koronavirus smatrali su da su knjižnice mjesta „niskog rizika“ te da su među prvima spremne za ponovno otvaranje jer je ljudski kontakt u njihovim prostorima vrlo malen. Mnogi knjižničari javno su iskazali svoje nezadovoljstvo što je rezultiralo naknadnim izmjenama preporuka. ${ }^{5}$

U travnju 2020. godine članovi EBLIDA-e sudjelovali su u istraživanju uvjeta u kojima rade knjižnice tijekom krize koronavirusa. Predstavljeno je preliminarno izvješće koje navodi pet novih normalnosti u razdoblju nakon koronavirusa, tj. područja u kojima je koronavirus promijenio način rada knjižnica, a to su redom: eksponencijalna fizička udaljenost koja podrazumijeva dobru povezanost unutar knjižnice, ali držanjem razmaka od dva metra, pri čemu se javlja bojazan o uvođenju samoposluživanja, smanjenju broja knjižničara, a izostaje i koncept knjižnica kao prostora dnevnog boravka zajednice; nove tehnologije koje nanovo oblikuju knjižnice promoviraju online izvore i usluge, virtualne programe i događanja, pri čemu se postavlja pitanje kvalitete; ekonomski aspekt koji podrazumijeva pregled knjižničnog proračuna i financijski problemi u 2021. godini - rezanje financijskih proračuna odrazit će se na programe knjižnica, ali i na društvenu ulogu koju knjižnica nudi; upravljanje knjižnicama na središnjoj i lokalnoj razini koja utječe na uvođenje inovativnih usluga i prilagodbu postojećih; i na kraju ne treba zaboraviti prilike i prijetnje koje uzrokuju klimatske promjene, 2020. godina bila je iznenađujuće dobra godina govori li se o klimatskim promjenama, zbog trenutne epidemiološke situacije mnoge tvornice bile su prisiljene zatvoriti postrojenja, a smanjila se i emisija ispušnih plinova zbog manjeg broja automobila na cestama. ${ }^{6}$

\footnotetext{
4 Usp. Ashworth, B. Covid-19's impact on libraries goes beyond books. // Wired. 2020. [citirano: 2020-11-09]. Dostupno na: https://www.wired.com/story/covid-19-libraries-impact-goes-beyond-books/.

5 Usp. Rosenbaum, L. Johns Hopkins changed its guidance on re-opening the economy after pushback from librarians. // Forbes. 2020. [citirano: 2021-01-16]. Dostupno na: https://www. forbes.com/sites/leahrosenbaum/2020/04/23/johns-hopkins-changed-its-guidance-on-re-opening-the-economy-after-pushback-from-librarians/?sh=35206e7d71a2 .

6 Usp. EBLIDA. A European library agenda for the post-Covid 19 age: [work in progress]: draft, May 2020. [citirano: 2020-11-13]. Str. 4-7. Dostupno na: http://www.eblida.org/Documents/ EBLIDA-Preparing-a-European-library-agenda-for-the-post-Covid-19-age.pdf.
} 
Iznimne okolnosti mogu zahtijevati nove modele upravljanja knjižnicama i, istodobno, pojačanje postojećih. ${ }^{7}$ Financijske poteškoće posebno će, kao što je prethodno istaknuto, biti vidljive 2021. godine, a proračuni knjižnica bit će u poteškoćama zbog dva bitna razloga: prvi je činjenica da se knjižnice velikim dijelom financiraju iz lokalne samouprave, a drugi razlog podrazumijeva nepromjenjivost određenih knjižničnih troškova, što znači da će patiti društveni vid financiranja, troškovi aktivnosti koji se tiču knjižnice kao mjesta susreta lokalne zajednice.

\section{Online usluge Gradske knjižnice i čitaonice „Ivan Goran Kovačić“6 Karlovac}

Ovogodišnja Skupština Hrvatskog knjižničarskog društva održana je u hibridnom obliku. Otvorenje i pozvana izlaganja predstavljena su u predvorju Nacionalne i sveučilišne knjižnice u Zagrebu, a program se mogao pratiti uživo putem Zoom aplikacije. Tema 45. Skupštine nosila je prikladan naziv Knjižnice $u$ doba krize. Virtualni programi i online usluge karlovačke knjižnice predstavljeni su unutar podteme Knjižnične usluge i programi u kontekstu upravljanja kriznim situacijama. Bila je to sjajna prilika da se kolegama iz cijele Hrvatske predstavi prilagođeni program rada Gradske knjižnice „Ivan Goran Kovačićc“ Karlovac.

Kao i za sve knjižnice, i za karlovačku je 2020. godina bila prepuna izazova. $\mathrm{Na}$ krizu uzrokovanu koronavirusom knjižnica se prilagodila i reagirala na vrijeme. Program povodom obilježavanja rođendana knjižnice tradicionalno se provodi početkom ožujka, a tada kao da smo naslućivali što čeka i knjižnicu i njezine korisnike u drugoj polovici mjeseca. Naime, fokus jw programa u potpunosti bio usmjeren na digitalne usluge. ${ }^{8}$

Karlovačka knjižnica nudi sljedeće online usluge:

Upis i obnova članstva usluge su koje su uvedene 30. ožujka 2020. godine, u vrijeme kada je knjižnica bila zatvorena za korisnike. Upravo zato organiziran je online upis u knjižnicu ili produljenje postojećeg članstva koje je isteklo. Radi se o tri jednostavna koraka; potrebno je izvršiti uplatu internetskim bankarstvom, ispuniti online pristupnicu te ju s potvrdom o uplati poslati $e$-mailom. Od 1. travnja do 31. prosinca 2020. godine, karlovačka knjižnica bilježi ukupno 582 prva upisa korisnika te 4431 obnovu članstva postojećih korisnika. Od toga, online bilježi se tek 6 prvih upisa u knjižnicu (2 odrasla korisnika i 4 djece) i 24 obnove članstva (22 odrasla korisnika i 2 djece). Tome se može pribrojiti brojka od 100 upisa studenata Veleučilišta u Karlovcu online, od kojih su se čak 92 studenta prvi put upisala u knjižnicu, a 8 ih je tako obnovilo članstvo. Aktivnost je to koja se

\footnotetext{
Usp. isto, str. 21

8 Usp. E-knjižnica. // Gradska knjižnica „Ivan Goran Kovačić“. 2020. [citirano: 2021-01-16]. Dostupno na: http://www.gkka.hr/e-knjiznica-182-rodendan-knjiznice-uz-e-usluge/.
} 
provela u studenom 2020. godine u sklopu obilježavanja Dana hrvatskih knjižnica u okviru manifestacije Mjesec hrvatske knjige, u suradnji sa Studentskim zborom Veleučilišta u Karlovcu. ${ }^{9}$

Rezervacija knjiga e-mailom ili prijavom na online katalog pomoću broja članske iskaznice i osobnog PIN-a. Ta je usluga jedna od onih koje korisnici najviše koriste. Pojavom pandemije koronavirusa, broj zahtjeva naglo je porastao. Svaki dan zaprime se deseci $e$-mail zahtjeva korisnika, kao i online zahtjevi za rezervacijom knjiga putem prijave na online katalog.

U iznimnim slučajevima nudi se i plaćanje zakasnine internetskim bankarstvom. U tom slučaju moguće je izvršiti uplatu, poslati potvrdu o uplati, pa čak i knjige poštom. U 2020. godini bilježe se samo dva takva slučaja, jedan iz Republike Hrvatske te jedan iz inozemstva.

E-iskaznica može se otvoriti online katalogom, potreban je broj članske iskaznice i PIN, kao i za prijavu na katalog. Mogućnost otvaranja $e$-iskaznice za korisnike uvedena je u svibnju 2020. godine.

E-knjiga usluga je koja je uvedena 2. ožujka 2020. godine povodom obilježavanja 182. rođendana karlovačke knjižnice. $E$-knjigu moguće je posuditi aplikacijom za korištenje $e$-knjiga Zaki book, koja se može besplatno preuzeti na platformama Google Play (za Android), App Store (za iOS) i Microsoft Store (Windows 10), a u aplikaciju se ulazi prijavom pomoću broja članske iskaznice i PIN-a. Dostupno je oko 250 naslova beletristike, dječje i stručne literature. Preko aplikacije korisnici mogu pretražiti naslove, zadužiti i razdužiti knjigu te povećati i smanjiti slova. Zbog ograničenog broja licenci moguće je posuditi dvije knjige odjednom, a četiri naslova mjesečno, što ne umanjuje broj posuđenih knjiga u fizičkim odjelima i bibliobusnoj službi - korisnik odjednom može imati posuđena dva primjerka $e$-knjige, tri tiskane knjige kao i tri jedinice AV-građe. Aplikacija se može koristiti na 4 uređaja istovremeno, a rok posudbe $e$-knjige iznosi 21 dan bez mogućnosti produljenja roka posudbe - ne moraju se poduzimati dodatne radnje nego program jednostavno „povuče“ knjigu i više je nema u aplikaciji bez dodatnih troškova, odnosno zakasnine. Od uvođenja usluge do 31. prosinca 2020. godine ukupno su posuđena 1562 primjerka $e$-knjige od čega: 185 primjeraka naslova iz područja publicistike, 1352 primjerka beletristike i 25 primjeraka naslova dječje literature. Navedene primjerke ukupno je posudio 281 korisnik knjižnice.

Digitalizirani karlovački tisak i baština. Radi se o digitalnoj zbirci koja uključuje novu platformu digitaliziranog Karlovačkog tjednika, tjednika za politiku, prosvjetu i narodno gospodarstvo „Hrvatska sloboda“, najdugotrajnijeg karlovačkog kalendara „Karlstädter Schreib-Kalender“, pučkog kalendara „Karlovački

9 Usp. Dan hrvatskih knjižnica 2020. uz dvije akcije. // Gradska knjižnica „Ivan Goran Kovačić“". 2020. [citirano: 2021-01-17]. Dostupno na: http://www.gkka.hr/dan-hrvatskih-knjiznica-2020-uz-dvije-akcije/. 
Šoštar“, kalendara „Prorok“ i kalendara „Nada“. U 2019. godini digitalnoj zbirci, putem poveznice na mrežnoj stranici knjižnice, pristupila su 543 korisnika, a u 2020. godini čak 1100 korisnika, pri čemu se bilježi povećanje od čak 102,6 \%. Digitalizirani su i članci o Domovinskom ratu iz časopisa "Svjetlo“. ${ }^{10}$ Digitalizirana karlovačka baština obuhvaća: knjigu posjetitelja Ilirske čitaonice „Upisna knjiga posjetiteljah Ilirske čitaonice karlovačke“, monografiju „,Tri siela narodne čitaonice karlovačke“ i fotomonografiju „Grad Karlovac i njegova okolica“."11

Otvoreni pristup virtualnoj referentnoj zbirci (poveznice na biografije, rječnike, enciklopedije, priručnike i statistike), $e$-knjigama, $e$-časopisima i bazama podataka.

Društvene mreže; knjižnica je prisutna i na društvenim mrežama, tako su na Facebooku otvoreni sljedeći profili: Gradska Knjižnica „Ivan Goran Kovačić“ Karlovac, Dječji odjel Gradske knjižnice „I. G. Kovačić“, Bibliobus Karlovac, Središnja knjižnica Slovenaca u RH i Knjižnica za mlade Karlovac, koja ujedno ima i Instagram profil. Na otvorenim profilima redovito se objavljuju novosti u knjižnici, obavijesti za korisnike, preporuke za čitanje, događanja u knjižnici, videozapisi radionica i čitaonica kao i korisni sadržaji s drugih poveznica. Na primjeru analize analitike Facebook profila Gradska knjižnica „Ivan Goran Kovačićc Karlovac (stranica napravljena 2015. godine), svojevrsnog „krovnog“ profila na kojem se objavljuje najveća količina sadržaja koji se odnosi na sve odjele knjižnice i koji posjećuje najveći broj korisnika, zaključuje se: krajem 2019. godine, profil knjižnice imao je 2864 pratitelja, a krajem 2020. godine taj se broj povećao na 3156 te se primjećuje povećanje od 10,2\%. Krajem 2019. godine broj oznaka „sviđa mi se“ bio je 2842, a krajem 2020. godine 3120; bilježi se porast od 9,8 \%. ${ }^{12}$ Budući da je knjižnica od 17. ožujka do 27. travnja bila zatvorena za korisnike, a potom radila prema ograničenom sustavu rada, ne čudi pojačano korištenje društvenih mreža od strane korisnika kao glavnog načina informiranja o uslugama i aktivnostima knjižnice.

YouTube kanal na kojem se redovito objavljuju videozapisi programa i aktivnosti napravljen je u siječnju 2020. godine. Kanal ima 43 pretplatnika, 6345 pregleda i 74 objavljena videozapisa. ${ }^{13}$

Online usluge karlovačke knjižnice postojale su i prije pojave koronavirusa, a neke su uvedene kao rezultat ograničenog sustava rada za korisnike; to se prvenstveno odnosi na uslugu online upisa i obnove članstva. Mogućnost posudbe e-knjige

\footnotetext{
10 usp. Digitalizirani karlovački tisak. (citirano: 2021-01-20). Dostupno na: http://www.gkka.hr/ digitalizirani-karlovacki-tisak/.

11 usp. Digitalizirana karlovačka baština. (citirano: 2021-01-20). Dostupno na: http://www.gkka. $\mathrm{hr} /$ digitalizirana-karlovacka-bastina/.

12 Podaci dobiveni analizom analitike Facebook stranice Gradske knjižnice „Ivan Goran Kovačić" Karlovac. [citirano: 2021-01-17]. Dostupno na: https://www.facebook.com/KnjiznicaKarlo$\mathrm{vac} /$.

13 Podaci na datum 17. siječanj 2021. godine.
} 
i YouTube kanal napravljeni su početkom 2020. godine, kada je pandemija koronavirusa već bila prisutna u svijetu. Važno je istaknuti važnost svih online usluga bilo postojećih ili novouvedenih, kao i činjenicu da sve imaju svoju ciljanu publiku.

\section{Virtualni programi za korisnike}

Dva su glavna cilja pokrenula korištenje tehnologija u knjižnici: bolje zadovoljenje potreba knjižnične zajednice i pojednostavljenje rada osoblja. Tehnologije koje su utjecale i nastavljaju vršiti utjecaj na rad knjižnica možemo podijeliti u tri skupine: tehnologije osmišljene posebno za poslovanje knjižnica, prilagođene tehnologije i tehnologije primjenjive u radu knjižnica bez ikakvih izmjena. ${ }^{14}$ Knjižnice danas u svom radu koriste pregršt novih besplatnih tehnologija i aplikacija pomoću kojih mogu provoditi raznovrsne programe, a gotovo da i nema knjižnice koja nije prisutna na društvenim mrežama ili, pak, nema svoj YouTube kanal. Gradska knjižnica „Ivan Goran Kovačić“ Karlovac virtualne je programe intenzivirala 2020. godine. Zbog epidemiološke situacije provođenje takvih vrsta programa započelo je u sklopu Noći knjige u travnju iste godine. Organizirani su književni susreti, $e$-izložbe, radionice za odrasle, radionice i čitaonice za najmlađe, edukativni videozapisi o knjižničnim uslugama, kvizovi, escape room, tečajevi stranih jezika i sastanci čitateljskih klubova. Videozapisi aktivnosti redovito su objavljivani na Facebook stranici i YouTube kanalu knjižnice.

Virtualni susret organiziran je s putopiscem i novinarom Hrvojem Ivančićem, koji je predstavio svoje tri objavljene knjige - Za'atar: priče s Bliskog istoka, Dunavski Blues i Samsara: put na Istok, ali i komentirao trenutačnu situaciju u društvu te govorio o porivima za putovanjima. ${ }^{15}$ Književni susret održan je i s karlovačkom književnicom Ivanom Francišković Olrom, prilikom kojeg je predstavila novu priču „Kako je Danko postao stablo“ ${ }^{16}$ Knjižnica za mlade organizirala je književni susret s autoricom Tanjom Radović prikladnog naziva „U 4 zida“. ${ }^{17}$

Edukativni videozapisi pripremljeni su o sljedećim temama: korištenje usluge Zaki book, ${ }^{18}$ slovenski jezik i kultura ${ }^{19}$ te korištenje slovenske digitalne platforme

\footnotetext{
14 Usp. Burke, J. Nav. dj., str. 4.

15 Online književne brbljaonice: gost Hrvoje Ivančić. // YouTube. [citirano: 2021-01-18]. Dostupno na: https://www.youtube.com/watch?v=FGgvSlV2Tgw.

16 Virtualni književni susret s Ivanom Francišković Olrom. // YouTube. [citirano: 2020-01-18]. Dostupno na: https://www.youtube.com/watch?v=zhGNZ-OBUxs.

17 U 4 zida. // YouTube. [citirano: 2021-01-18]. Dostupno na: https://www.youtube.com/wat$\mathrm{ch}$ ? $\mathrm{v}=\mathrm{Uy}-\mathrm{kRgAP}-\mathrm{S} 0$.

18 E-knjige uz Zaki Book. // YouTube. [citirano: 2021-01-18]. Dostupno na: https://www.youtube.com/watch? $\mathrm{v}=\mathrm{BvS} 8 \mathrm{R} 2 \mathrm{PgsvE}$.

19 Slovenski jezik i kultura online. // YouTube. [citirano: 2021-01-18]. Dostupno na: https:// www.youtube.com/watch?v=Dms9yuZiocA.
} 
za posudbu $e$-knjiga, Biblos ${ }^{20}$. Svi zapisi snimljeni su pomoću besplatnog alata za snimanje, Loom. Korisnici su tako naučili kako posuditi i čitati $e$-knjigu, upoznali Sloveniju i Slovence, saznali o mogućnosti besplatnog učenja slovenskog jezika u karlovačkoj knjižnici, upoznali se sa slovenskom kulturom i poviješću. U kratkoj edukaciji o učenju slovenskoga jezika te korištenju odabranih digitalnih zbirki i portala saznali su po čemu je Slovenija prepoznatljiva i posebna u svijetu.

Čitateljski klubovi također su se sastajali virtualno, tako su članovi čitateljskog kluba ljubitelja poezije Stihom u srce čitali svoju poeziju preko Facebooka ${ }^{21}$, a čitateljski klub Cheetaj napravio je svojevrsnu virtualnu izložbu o svoje četiri godine postojanja pod nazivom „Virtualnih četiri“. ${ }^{22}$

Radionice za djecu snimale su djelatnice Odjela za predškolski uzrast, ${ }^{23}$ a za odrasle organizirana je virtualna radionica izrade uveza knjige pod nazivom „Knjige imaju svoju sudbinu“24. „Knjiška putovanja“ naziv je videozapisa u tehnici animacije stop-motion pomoću kojih su predstavljena putovanja uz pomoć pustolovnih i avanturističkih dječjih knjiga. ${ }^{25} \mathrm{Na}$ taj se način djecu poticalo na savladavanje tehnike animacije uz poveznice na stranice koje objašnjavaju postupak. Redovito su se objavljivali videozapisi čitanja slikovnica najmlađim korisnicima ${ }^{26}$ a za odrasle korisnike osmišljena je rubrika \#ostanisknjigom ${ }^{27}$ u kojoj se redovito objavljuju preporuke za čitanje. Na mrežnoj stranici knjižnice objavljeno je 28 preporuka za čitanje iz područja beletristike, dok Facebook stranica knjižnice broji 17 objava. Online kvizove s pitanjima iz raznih područja ${ }^{28}$ i virtualni es-

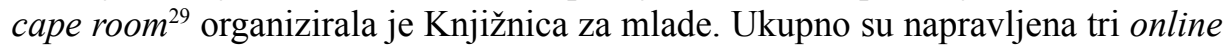

20 E-knjige na slovenskom jeziku - platforma Biblos. // YouTube. [citirano:2021-01-18]. Dostupno na: https://www.youtube.com/watch?v=scz23ge-OZ8.

${ }^{21}$ Klub ljubitelja poezije „Stihom u srce“. // Gradska knjižnica „Ivan Goran Kovačić“ Karlovac Facebook. [citirano: 2021-01-18]. Dostupno na: https://www.facebook.com/869344363107572/ videos/560313331356536, i na: https:/www.facebook.com/869344363107572/videos/2590406474569305.

22 Virtualnih četiri.// YouTube. [citirano: 2021-01-18]. Dostupno na: https://www.youtube.com/ watch? $\mathrm{v}=$ kcgRRwcPdI.

23 Uskršnja radionica: izrada čestitki. // YouTube. [citirano: 2021-01-18]. Dostupno na: https:// www.youtube.com/watch?v=6Xxz5uOIxr4.

24 Radionica uveza knjige: Knjige imaju svoju sudbinu. // YouTube. [citirano: 2021-01-18]. Dostupno na: https://www.youtube.com/watch?v=cOD5_wrPrd8.

${ }_{25}$ Knjiška putovanja 1. // YouTube. [citirano: 2021-01-18]. Dostupno na: https://www.youtube. com/watch?v=5aiKhx9Y6I0.

26 Čitaonica: Ježica Vici u šumskoj češljaonici. // YouTube. [citirano: 2021-01-18]. Dostupno na: https://www.youtube.com/watch?v=QAkUTtYIncQ.

27 \#ostanisknjigom. // Gradska knjižnica „Ivan Goran Kovačić“. [citirano: 2021-01-18]. Dostupno na: http://www.gkka.hr/ostanisknjigom/.

28 Razlistana pitanja. [citirano: 2021-01-18]. Dostupno na: https://tinyurl.com/y2bet5y6

29 EscapeRoom: „Koja je prava šifra?“ [citirano: 2021-01-18]. Dostupno na: https://tinyurl.com/ y3zqzulg. 
kviza; prvi je imao 98 ispunjenih obrazaca, drugi 41, a treći 14; ukupno 153 osobe odigrale su online kvizove, no iz navedenih brojki vidljiv je pad zainteresiranosti za tu vrstu aktivnosti. Prethodnih godina na kvizovima su sudjelovale srednje škole s peteročlanim ekipama, a broj škola koje su sudjelovale kretao se od tri do pet. Obrazac za escape room ne bilježi posjete pa nisu izneseni podaci za tu aktivnost.

Zbog nemogućnosti postavljanja izložbe radova učenika Srednje škole Duga Resa nastalih u okviru projekta „Ilustracije hrvatskih mitova i legendi“, izložba „Hrvatske legende u virtualnom svijetu“ postavljena je virtualno, ${ }^{30}$ kao i online izložba fotografija sudionika radionice koja se treću godinu zaredom provodi u Knjižnici za mlade, „Mobitel nije samo selfie“"31. Radionica fotografiranja mobilnim uređajima za cilj je imala zabaviti sve sudionike i kroz objektiv kamere mobitela osmisliti priču o vremenu provedenom u izolaciji tijekom travnja 2020. godine. Motivi su bili različiti, uglavnom vezani uz životni prostor. Kako je spomenuto, radionica je organizirana i prethodnih godina, a u prvom ciklusu koji se odvijao u prostoru Knjižnice za mlade osobno sudjelovalo je 10 polaznica, koje su svoje radove predstavile i na izložbi. Drugi ciklus radionica nije završen zbog pojave koronavirusa te je upravo zato organiziran online natječaj na koji su fotografije mogli poslati svi zainteresirani. Na natječaj su pristigle fotografije 22 sudionika, čiji radovi su spojeni u virtualnu izložbu.

Na mrežnoj stranici knjižnice dostupna je i poveznica $e$-izložbe „Sve naše zgrade" rađene pomoću alata Timeline ${ }^{32}$. Izložbu su izradili djelatnici knjižnice koji su sudjelovali na predavanju i radionici „Proces izrade virtualnih izložbi““ održanima u studenom 2019. godine u organizaciji Županijske matične službe.

Besplatni tečaj švedskog jezika u Knjižnici za mlade provodi se od 2017. godine. Broj prijavljenih osoba tada je bio 53 , a primalo se 25 polaznika po grupi. U ostalim ciklusima broj polaznika varirao je od 10 do 20 , a tečaj se održavao u prostoru Knjižnice za mlade. Godine 2020. tečaj se odvijao na daljinu putem Skypea, a iako je broj mjesta mogućih sudionika bio 10, na tečaj su se prijavile te ga završile samo 4 osobe.

Besplatni tečaj slovenskog jezika od 2017. godine provodi Središnja knjižnica Slovenaca u Republici Hrvatskoj koja djeluje u sastavu Gradske knjižnice „Ivan Goran Kovačićc Karlovac, a financijski ga podupire Ured Vlade Republike Slovenije za Slovence v zamejstvu in po svetu. Tečaj je otvoren za građane i korisnike knjižnice, a provodi ga iskusan profesor slovenskog jezika. Tečaj se tradicionalno provodi u prostoru knjižnice, a 2020. godine održan je na daljinu. Za realizaciju učenja na daljinu koristile su se sljedeće obrazovne internetske platforme: mrežna stranica te-

\footnotetext{
30 Hrvatske legende u virtualnom svijetu. // YouTube. [citirano: 2021-01-18]. Dostupno na: https://www.youtube.com/watch?v=mvV115TdXew.

31 Mobitel nije samo selfie - online foto izložba. // YouTube. [citirano: 2021-01-18]. Dostupno na: https://www.youtube.com/watch?v=Oxq_zUO_zqI.

32 Sve naše zgrade. [citirano: 2021-01-18]. Dostupno na: https://tinyurl.com/y35h5hmb.
} 
čaja koje je dostupna na mrežnoj stranici Gradske knjižnice „Ivan Goran Kovačić“ i koja korisnicima pruža sve važne informacije u vezi s načinima provođenja tečaja te na kojoj se nalaze svi audio-vizualni materijali za svaku skupinu, Google učionica i online satovi pomoću aplikacije Zoom whiteboard, gdje svaka grupa ima zajedničku lekciju s profesorom svaki tjedan. U 2019. godini, kada se nastava održavala uživo, tečaj je upisalo 49 , a završilo 23 polaznika. 2020. godina bilježi pad zainteresiranosti sugrađana; tečaj je upisalo 35 osoba, a završilo tek 10 polaznika.

U tablici 1 prikazani su pregledi postavljenih sadržaja na Facebook stranici i YouTube kanalu knjižnice. ${ }^{33}$ Valja istaknuti da se određeni sadržaj objavljivao na više profila, a za potrebe rada prikazani su podaci preuzeti s krovnog profila Gradska knjižnica „Ivan Goran Kovačič“ Karlovac koji bilježi najviše posjeta korisnika.

Tablica 1. Prikaz pregleda sadržaja

\begin{tabular}{|l|c|c|}
\hline Aktivnost & $\begin{array}{c}\text { Broj pregleda na } \\
\text { Facebook stranici } \\
\text { knjižnice }\end{array}$ & $\begin{array}{c}\text { Broj pregleda na } \\
\text { YouTube kanalu } \\
\text { knjižnice }\end{array}$ \\
\hline $\begin{array}{l}\text { Književni susret s Hrvojem } \\
\text { Ivančićem }\end{array}$ & 600 & 438 \\
\hline Književni susret s Tanjom Radović & 190 & 58 \\
\hline $\begin{array}{l}\text { Književni susret s Ivanom } \\
\text { Francišković Olrom }\end{array}$ & 398 & 226 \\
\hline $\begin{array}{l}\text { Edukativni videozapis o korištenju } \\
\text { usluge Zaki Book }\end{array}$ & 552 & 127 \\
\hline $\begin{array}{l}\text { Edukativni videozapis o slovenskom } \\
\text { jeziku i kulturi }\end{array}$ & 438 & 369 \\
\hline Edukativni zapis o platformi Biblos & 366 & 26 \\
\hline $\begin{array}{l}\text { Čitateljski klub „,Stihom u srce“ } \\
\text { (3 videozapisa na Facebooku i 1 } \\
\text { videozapis na YouTubeu) }\end{array}$ & 763 & 132 \\
\hline $\begin{array}{l}\text { Izložba Virtualnih četiri čitateljskog } \\
\text { kluba Cheetaj }\end{array}$ & 344 & 64 \\
\hline Radionica za odrasle & 355 & 116 \\
\hline Radionice za djecu (14 radionica) & 17605 & 1585 \\
\hline Čitaonice za djecu (13 čitaonica) & 7250 & 832 \\
\hline Knjiška putovanja (3 videozapisa) & 812 & 139 \\
\hline $\begin{array}{l}\text { „lustracije hrvatskih mitova i } \\
\text { legendi“ - }- \text {-izložba }\end{array}$ & 226 & 143 \\
\hline
\end{tabular}

33 Podaci na datum 19. siječanj 2021. godine. 


\begin{tabular}{|l|c|c|}
\hline Aktivnost & $\begin{array}{c}\text { Broj pregleda na } \\
\text { Facebook stranici } \\
\text { knjižnice }\end{array}$ & $\begin{array}{c}\text { Broj pregleda na } \\
\text { YouTube kanalu } \\
\text { knjižnice }\end{array}$ \\
\hline $\begin{array}{l}\text { „Mobitel nije samo selfie““، }- \\
e \text {-izložba }\end{array}$ & 617 & 136 \\
\hline Online kviz (3 kviza) & 1139 & nije postavljen \\
\hline Escape room & 415 & nije postavljen \\
\hline
\end{tabular}

Iz priložene tablice vidljivo je da je korisničko praćenje objava aktivnosti knjižnice u mnogo većoj mjeri zastupljeno na društvenoj mreži Facebook u odnosu na YouTube kanal. Sadržaj koji je na objema platformama imao najviše pregleda onaj je za dječji i predškolski uzrast. Uočene su mane postojanja pet različitih Facebook stranica za knjižnicu i pojedine odjele te bi u budućnosti, za kvalitetnije praćenje statistike, uvelike bilo zahvalnije ograničavanje na jedan zajednički profil.

Produkcija virtualnih programa iziskuje poznavanje web-alata i digitalnih platformi, a s radom nekih od njih djelatnici karlovačke knjižnice upoznali su se uslijed i radi pojave koronavirusa. Djelatnici su se educirali samostalno, videozapisi snimali su se od kuće, a u pojedinim slučajevima, kada je situacija to zahtijevala (nedostatak opreme kod kuće), snimalo se unutar prostora knjižnice. Prilikom snimanja čitaonica za djecu vođena je briga o poštivanju autorskih prava; kontaktirani su nakladnici u čijoj nakladi su djela izašla, a prilikom stavljanja videozapisa čitanja cjelovitih slikovnica, navedeni su autor i ilustrator djela te nakladnik. U prvoj fazi pojave koronavirusa, točnije u proljeće 2020. godine, nakladničke kuće pojačano su poticale čitanje svojih naslova.

Prilikom osmišljavanja i provođenja programa najveći nedostatak bilo je - vrijeme. Planirana događanja bila su otkazana pa je trebalo osmisliti način kako ih u kratkom roku prebaciti u virtualni svijet. Stručna usavršavanja koja djelatnici prolaze tijekom godina uvelike su olakšala provedbu programa. Usprkos online inačicama programa koji nisu mogli biti održani uživo, ipak je vidljiv pad zainteresiranosti za neke od njih, posebice tečajeve stranih jezika, gdje sudionici pokazuju veći interes za pristup uživo.

\section{Ispitivanje zadovoljstva korisnika online uslugama i virtualnim programima knjižnice}

Anketno ispitivanje zadovoljstva korisnika ponuđenim online uslugama i virtualnim programima karlovačke knjižnice provedeno je u siječnju 2021. godine. Anketni upitnik objavljen je na Facebook stranici knjižnice 8. siječnja, a do 20. siječnja ispunila ga je 71 osoba (vidi prilog 1). Za izradu obrasca, najprikladnijim se pokazao besplatni Google alat za izradu anketa, Google dokumenti (Google 
docs). Ispunjavanje upitnika koji se sastojao od 15 pitanja bilo je anonimno. Prvi dio upitnika sastojao se od pitanja koja se odnose na podatke o ispitanicima kao što su spol, starosna dob, jesu li članovi knjižnice te ako jesu, uslugama kojih odjela knjižnice se koriste. Drugi dio posvećen je poznavanju i korištenju online usluga, a slijedi dio o poznavanju i praćenju virtualnih programa knjižnice. Na kraju upitnika, ispitanici su se izjasnili o tome je li im draži osobni dolazak u knjižnicu ili korištenje online usluga i praćenje virtualnih programa.

Svrha provedenog istraživanja bila je praćenje zadovoljstva korisnika postojećim uslugama, kao i njihovo poboljšanje te uvođenje novih programa u budućem radu knjižnice.

\subsection{Rezultati ispitivanja}

Prvo pitanje ankete odnosilo se na spol ispitanika. Od 71 ispunjenog upitnika, $76,1 \%$ ispitanika izjasnilo se ženama (54 ispitanica), a 23,9 \% muškarcima (17 ispitanika), čime je vidljiva veća posjećenost Facebook stranice knjižnice od strane žena, što ne čudi jer 62,8 \% članova knjižnice čine upravo žene. ${ }^{34}$ Drugo pitanje odnosilo se na starosnu dob ispitanika, ponuđeno je pet starosnih kategorija (vidi sliku 1), a najviše ispitanika, 39,4\%, odabralo je kategoriju od 26 do 37 godina. Zabrinjava činjenica da su ispitanici koji po godinama mahom pripadaju kategoriji studenata u najmanjoj mjeri ispunili upitnik (samo 3 ispitanika). To se može pripisati nezainteresiranosti mlađe populacije za ispunjavanjem anketnih upitnika ili razdobljem kada se studenti pripremaju za ispitne rokove.

\section{Starosna dob}

71 responses

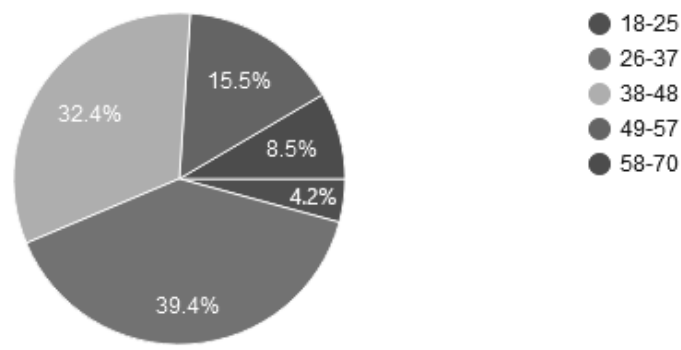

Slika 1. Starosna dob ispitanika

34 Izvješće o radu Gradske knjižnice „Ivan Goran Kovačić““ Karlovac za 2019. godinu str. 8. [citirano: 2021-01-23]. Dostupno na: http://www.gkka.hr/wp-content/uploads/2020/05/Izvje\%C5\%A1\%C4\%87e-Gradske-knji\%C5\%BEnice-Ivan-Goran-Kova\%C4\%8Di\%C4\%87-Karlovac-za-2019.-godinu.pdf. 
Treće pitanje odnosilo se na podatak jesu li ispitanici članovi knjižnice. Od ukupno 71 odgovora, njih 95,8\% (68 ispitanika) bilo je potvrdno, a samo 4,2\% negativno (3 ispitanika), s obzirom na to da je anketni upitnik ispitanicima bio dostupan na Facebook stranici knjižnice, podrazumijeva se da su posjetitelji te stranice u velikoj mjeri i članovi knjižnice. Četvrto pitanje od ispitanika je tražilo da navedu odjele čijim uslugama se koriste. Na to je pitanje odgovorilo 69 ispitanika, što ukazuje na činjenicu da je na njega odgovorila jedna osoba koja nije član knjižnice, što se može interpretirati tako da se osoba koristi članskom iskaznicom člana obitelji ili prijatelja. Najveći broj ispitanika, njih 79,7 \% najviše se koristi uslugama Informativno-posudbenog odjela kao i Odjela za djecu i mladež, njih 44,9\%. Najmanje ispitanika, samo 4,3 \%, koristi usluge Knjižnične stanice Švarča, koja je za korisnike otvorena samo dva dana u tjednu, pa je dobiveni rezultat razumljiv (vidi sliku 2).

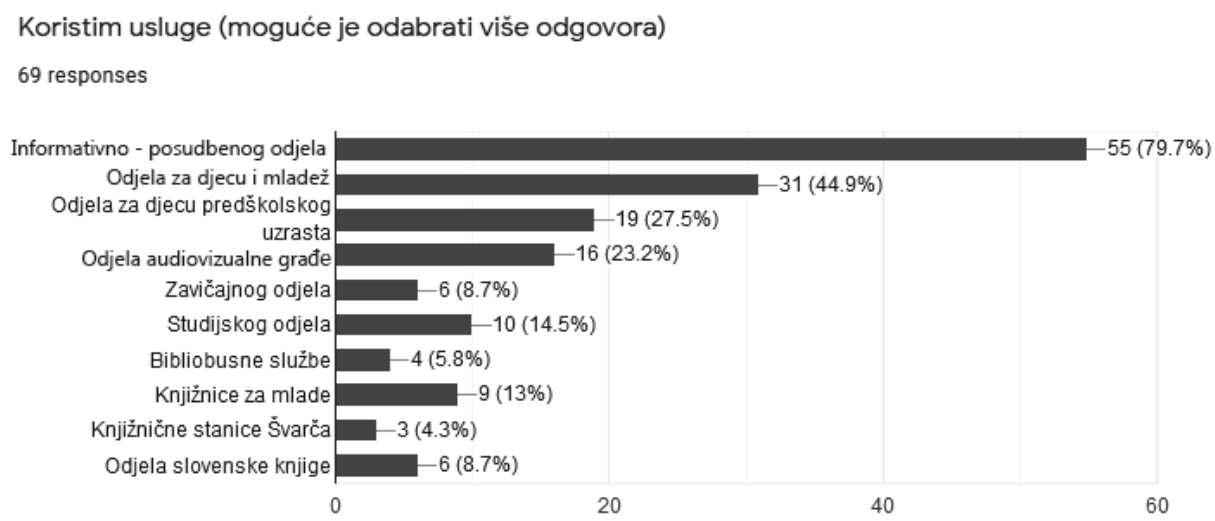

Slika 2. Korištenje usluga pojedinih odjela knjižnice

Drugi dio anketnog upitnika odnosio se na online usluge. Peto pitanje od ispitanika je tražilo da se izjasne jesu li upoznati s online uslugama karlovačke knjižnice. Na to pitanje odgovorilo je 69 ispitanika, od kojih 92,8 \% potvrdno, a 7,2 \% negativno. Podatak je to koji motivira razvijanje novih online usluga, kao i zadovoljstvo načinom knjižnične promocije istih. Na šesto pitanje, kao i na četvrto, ispitanici su mogli odabrati više ponuđenih odgovora. Ne čudi podatak da najviše ispitanika koristi društvene mreže i YouTube kanal, njih 59,1 \%, kao i uslugu rezervacija knjiga, koju koristi $42,4 \%$ ispitanika. Usluga posudbe $e$-knjige također ima dobru posjećenost korisnika, što ukazuje na potrebu za povećanjem nabave broja dostupnih naslova (vidi sliku 3). Ostale online usluge koriste se u podjednakoj mjeri. 
Vjesnik bibliotekara Hrvatske 64, 1(2021), 175-199

Koristim (koristio/la sam) sljedeće online usluge (moguće je odabrati više odgovora)

66 responses

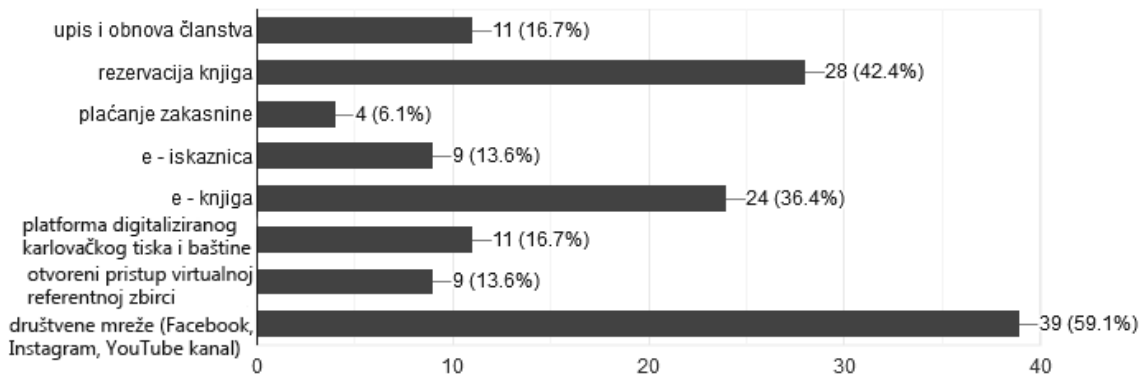

Slika 3. Online usluge knjižnice

Većina ispitanika, njih 49,2 \%, online uslugama u potpunosti je zadovoljna ili zadovoljna (47,7 \%) no bilježi se i rezultat jednog korisnika koji uslugama uopće nije zadovoljan (vidi sliku 4).

Molimo, ocijenite zadovoljstvo postojećim online uslugama

65 responses

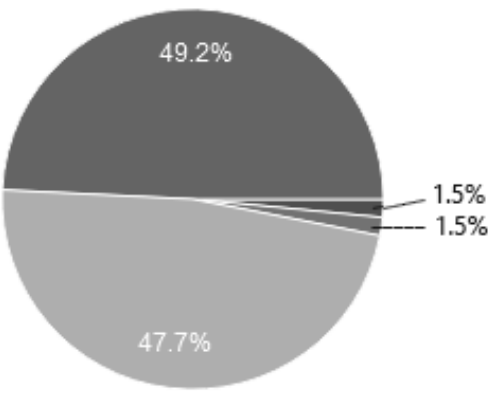

uopće nisam zadovoljan

donekle sam zadovoljan

zadovoljan sam

u potpunosti sam zadovoljan

Slika 4. Stupanj zadovoljstva korisnika online uslugama

Za online usluge ispitanici su u podjednakoj mjeri doznali prilikom osobnog dolaska u knjižnicu ili na mrežnoj i Facebook stranici knjižnice. Pohvalna je stoga uloga knjižničara u svakodnevnoj komunikaciji s korisnicima, a porazna činjenica da je najmanje ispitanika za online usluge doznalo iz medija, samo njih 8 , te bi knjižnica svakako trebala nastojati ojačati suradnju s medijima u vidu promocije usluga i aktivnosti (vidi sliku 5). 
Kako ste saznali za online usluge koje knjižnica nudi? (moguće je odabrati više odgovora) 65 responses

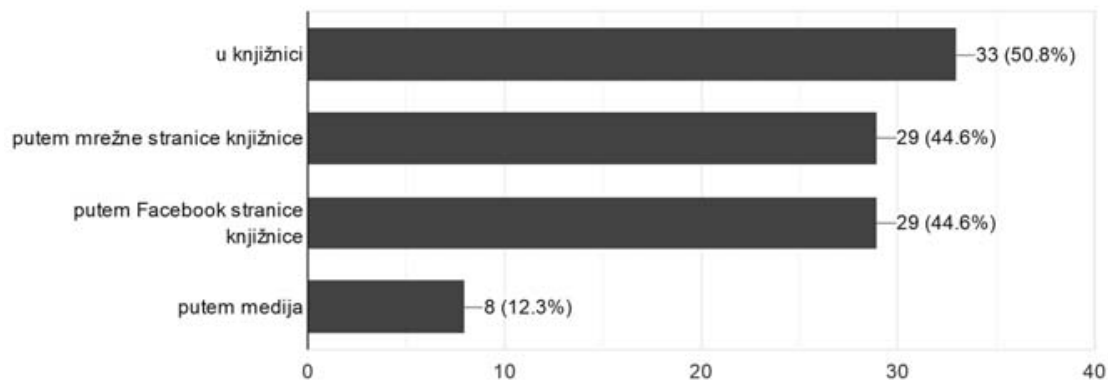

Slika 5. Saznanje o online uslugama

Ispitanici su mogli dati prijedloge za online usluge koje, po njihovu mišljenju, knjižnica nema, a tu mogućnost iskoristilo je 7 ispitanika dajući prijedloge poput mobilne aplikacije, implementacije Rfid sustava, više obavijesti, više tečajeva za nezaposlene, kao i pomoć u integraciji društva te zvučne knjige. Kako karlovačka knjižnica posjeduje 332 jedinice zvučne građe (podaci iz siječnja, 2021. godine), dostupne za posudbu na Odjelu audiovizualne građe za sve dobne uzraste, a odgovor ispitanika pokazuje kako s dotičnom uslugom nije upoznat, uočena je potreba za njihovom dodatnom promidžbom.

U trećem dijelu upitnika ispitanicima su postavljena pitanja o virtualnim programima knjižnice. Od ukupno 67 odgovora, 80,6 \% ispitanika izjasnilo se da je pratilo virtualne programe knjižnice u 2020. godini. Najviše ispitanika pratilo je virtualne čitaonice i radionice za djecu; 47,3\%, odnosno 43,6 \% ispitanika (vidi sliku 6). Tome u prilog idu i podaci s Facebook stranice i YouTube kanala knjižnice, gdje navedene aktivnosti imaju najveći broj pregleda korisnika.

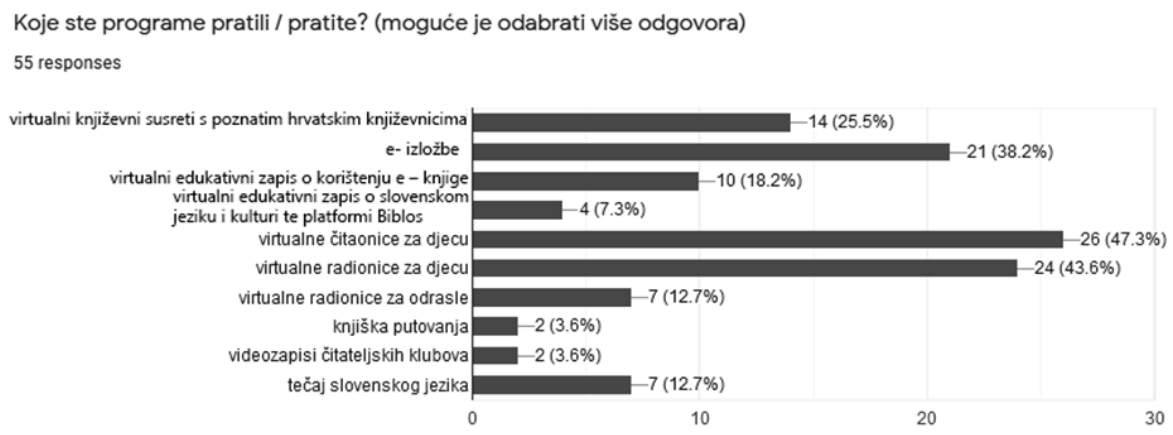

20

Slika 6. Virtualni programi 
Većina ispitanika zadovoljna je ili u potpunosti zadovoljna, a jedan ispitanik uopće nije zadovoljan ponuđenim virtualnim programima (vidi sliku 7).

Molimo, ocijenite zadovoljstvo virtualnim programima

55 responses

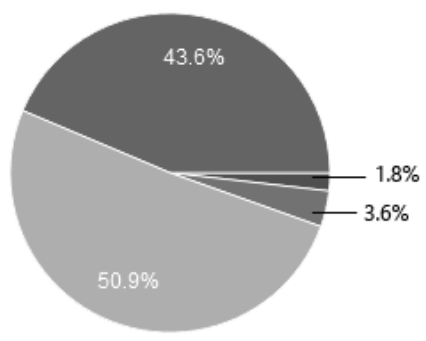

uopće nisam zadovoljan

donekle sam zadovoljan

zadovoljan sam

u potpunosti sam zadovoljan

Slika 7. Stupanj zadovoljstva korisnika virtualnim programima

Najveći broj ispitanika za virtualne programe saznao je na Facebook stranici knjižnice, 31 ispitanik, a zanimljivo je da niti jedan ispitanik za virtualne programe nije saznao na Instagramu (vidi sliku 8). Podatak je to koji ne čudi, jer Instagram profil ima samo Knjižnica za mlade. Na pitanje koje bi programe željeli vidjeti u budućnosti odgovorilo je 5 ispitanika odgovorima da knjižnica nudi sve.

Kako ste saznali za virtualne programe? (moguće je odabrati više odgovora)

55 responses

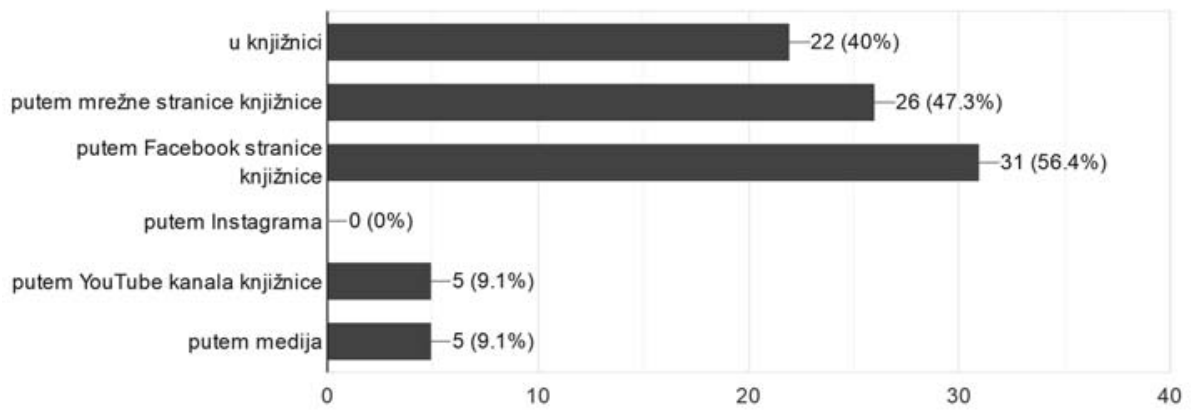

Slika 8. Saznanje o virtualnim programima 
Čak 95,8 \% ispitanika radije bira osobni dolazak u knjižnicu, dok samo tri ispitanika iskazuju veće zadovoljstvo korištenjem online usluga i virtualnim praćenjem programa (vidi sliku 9).

Je li Vam draži osobni dolazak u knjižnicu ili online usluge i virtualno praćenje programa? 71 responses

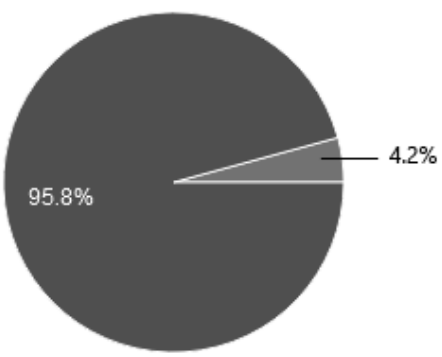

osobni dolazak

online / virtualne usluge

Slika 9. Korisničke preferencije praćenja knjižničnih programa

Provedeno ispitivanje zadovoljstva korisnika online uslugama i virtualnim programima karlovačke knjižnice daje podlogu za daljnji razvoj, kao i temelj za buduća istraživanja. Budući da u karlovačkoj knjižnici nije zabilježeno slično istraživanje u prošlosti, nije moguća usporedba s prethodnim podacima. Ispitivanje ima i svoja ograničenja, u prvom redu, mali broj ispunjenih anketnih upitnika, što može biti povezano s kratkotrajnom dostupnosti ispunjavanja upitnika; na Facebook stranici knjižnice anketa je bila postavljena u vidu istaknute objave 12 dana, nakon čega su na stranici postavljane nove objave vijesti i događanja u knjižnici te time upitnik automatski nije bio prvo što korisnici vide prilikom pregleda stranice. Zbog malog broja ispunjenih upitnika, uzeti su u obzir svi ispunjeni primjerci, uključujući i one gdje ispitanici nisu odgovorili na sva pitanja. Ispitivanje pokazuje da su korisnici u većoj mjeri zadovoljni uslugama knjižnice te ukazuje koje bi programe knjižnica trebala dodatno intenzivirati i na kojima bi trebalo poraditi u vidu usavršavanja usluge. Također, ispitivanje može usmjeriti rad knjižničara na ulaganje dodatnog napora pri promociji usluga i programa za mlađe dobne kategorije, kao i provedbu programa za osobe treće životne dobi.

\section{Zaključak}

Pandemija uzrokovana pojavom koronavirusa dodatno je ubrzala digitalnu transformaciju društva, a nastojanja knjižničarske zajednice u smislu jačanja kompetencija za novi način rada, nisu zanemariva. Edukacija knjižničara moguća je putem online radionica, webinara, online konferencija i stručnih skupova, surad- 
njom s drugim srodnim ustanovama i pojedincima koji posjeduju znanja potrebna za što kvalitetniju digitalnu uključenost. Jo Bryson u svojoj knjizi Managing information services: a sustainable approach ističe pet ključnih čimbenika uspješnosti koji osiguravaju uspjeh i održivost: razumijevanje okoline koja se mijenja, strategija i planiranje, vodstvo i inovacije, upravljanje i društvena odgovornost te usmjerenost na tržište i korisnike. ${ }^{35}$ Naglasak je postavljen na novim vještinama, načinu razmišljanja i pristupu poslovanju, a karlovačka knjižnica svojim radom u 2020. godini pokazala je upravo to; uspješno praćenje i stvaranje trendova poslovanja u skladu sa zahtjevima virtualnog okruženja.

Rezultati istraživanja zadovoljstva korisnika postojećim online uslugama i virtualnim programima poticaj su za daljnje razvijanje takvih vrsta usluga, kao i za dodatnu edukaciju knjižničara koja se u ovim vremenima pokazuje neizbježnom. Ulaganje u nove tehnologije nešto je čemu knjižnice moraju stremiti, te u skladu s time planirati financijsku konstrukciju poslovanja, a kako knjižnici tijekom 2021. godine slijedi evaluacija Strateškog plana knjižnice za razdoblje 2016. - 2020. godine, pruža se idealna prilika za unošenje promjena za novo razdoblje, koje se tiču novih uvjeta rada. Ovdje se prvenstveno misli na dio strateškog plana koji se odnosi na knjižnicu kao pokretača promjena i inovacija.

Provedeno anketno ispitivanje, uz sve svoje nedostatke, daje dobre smjernice daljnjeg djelovanja knjižnice u novim uvjetima. Predstavljeni programi i usluge, kao i statistički podaci korištenja istih, dokaz su uspješnog upravljanja knjižnicom u kriznoj situaciji, kao i kreativnog nastavka produkcije knjižničnih programa.

\section{LITERATURA}

Ashworth, B. Covid-19's impact on libraries goes beyond books. // Wired. 2020. [citirano: 2020-11-09]. Dostupno na: https://www.wired.com/story/covid-19-libraries-impact-goes-beyond-books/.

Bryson, J. Managing information services: a sustainable approach. Farnham: Ashgate, 2011.

Burke, J. Neal-Schuman Library Technology Companion: a basic guide for library staff. Chicago: Neal-Schuman, 2016.

Čitaonica: Ježica Vici u šumskoj češljaonici. // YouTube. [citirano: 2021-01-18]. Dostupno na: https://www.youtube.com/watch?v=QAkUTtYIncQ.

35 Usp. Bryson, J. Managing information services: a sustainable approach. Farnham: Ashgate, 2011. Str. xiv. 
Dan hrvatskih knjižnica 2020. uz dvije akcije. // Gradska knjižnica „Ivan Goran Kovačić“". 2020. [citirano: 2021-01-17]. Dostupno na: http://www.gkka.hr/dan-hrvatskih-knjiznica-2020-uz-dvije-akcije/.

Digitalizirana karlovačka baština. [citirano: 2021-01-20]. Dostupno na: http://www. gkka.hr/digitalizirana-karlovacka-bastina/.

Digitalizirani karlovački tisak. [citirano: 2021-01-20]. Dostupno na: http://www.gkka. $\mathrm{hr}$ /digitalizirani-karlovacki-tisak/.

E-knjige na slovenskom jeziku - platforma Biblos. // YouTube. [citirano:2021-01-18]. Dostupno na: https://www.youtube.com/watch?v=scz23ge-OZ8.

E-knjige uz Zaki Book. // YouTube. [citirano: 2021-01-18]. Dostupno na: https://www. youtube.com/watch?v=BvS8R2PgsvE.

E-knjižnica. // Gradska knjižnica „Ivan Goran Kovačić“،. 2020. [citirano: 2021-01-16]. Dostupno na: http://www.gkka.hr/e-knjiznica-182-rodendan-knjiznice-uz-e-usluge/.

EBLIDA. A European library agenda for the post-Covid 19 age: [work in progress]: draft, May 2020. [citirano: 2020-11-13]. Dostupno na: http://www.eblida.org/Documents/EBLIDA-Preparing-a-European-library-agenda-for-the-post-Covid-19-age. pdf.

EscapeRoom: „Koja je prava šifra?“ [citirano: 2021-01-18]. Dostupno na: https:// tinyurl.com/y3zqzulg.

Gradska knjižnica „Ivan Goran Kovačić““ Karlovac. // Facebook. [citirano: 2021-01-17]. Dostupno na: https://www.facebook.com/KnjiznicaKarlovac/.

Hrvatske legende u virtualnom svijetu. // YouTube. [citirano: 2021-01-18]. Dostupno na: https://www.youtube.com/watch? $\mathrm{v}=\mathrm{mvV} 115 \mathrm{TdXew}$.

IFLA. COVID-19 and the global library field. 2020. [citirano: 2020-11-06]. Dostupno na: https://www.ifla.org/covid-19-and-libraries.

Izvješće o radu Gradske knjižnice „Ivan Goran Kovačić“ Karlovac za 2019. godinu. [citirano: 2021-01-23]. Dostupno na: http://www.gkka.hr/wp-content/uploads $/ 2020 / 05 /$ Izvje $\%$ C5\%A $1 \%$ C4\%87e-Gradske-knji $\%$ C5\%BEnice-Ivan-Goran-Kova\%C4\%8Di\%C4\%87-Karlovac-za-2019.-godinu.pdf

Klub ljubitelja poezije „Stihom u srce“. // Gradska knjižnica „Ivan Goran Kovačić“ Karlovac Facebook. [citirano: 2021-01-18]. Dostupno na: https://www.facebook. com/869344363107572/videos/560313331356536, i na: https:/www.facebook. com/869344363107572/videos/2590406474569305.

Knjiška putovanja 1. // YouTube. [citirano: 2021-01-18]. Dostupno na: https://www. youtube.com/watch?v=5aiKhx9Y6I0.

Mobitel nije samo selfie - online foto izložba. // YouTube. [citirano: 2021-01-18]. Dostupno na: https://www.youtube.com/watch?v=Oxq_zUO_zqI. 
Modern libraries: moving from a transactional to a relational library. // Princh. [citirano: 2020-11-24]. Dostupno na: https://princh.com/modern-libraries-from-a-transactional-to-a-relational-library/\#.W4-eL-gzZEZ\%C5\%BE.

Online književne brbljaonice: gost Hrvoje Ivančić. // YouTube. [citirano: 2021-01-18]. Dostupno na: https://www.youtube.com/watch?v=FGgvSIV2Tgw.

\#ostanisknjigom. // Gradska knjižnica "Ivan Goran Kovačić". [citirano: 2021-01-18]. Dostupno na: http://www.gkka.hr/ostanisknjigom/.

Radionica uveza knjige: knjige imaju svoju sudbinu. // YouTube. [citirano: 2021-01-18]. Dostupno na: https://www.youtube.com/watch?v=cOD5_wrPrd8.

Razlistana pitanja. [citirano: 2021-01-18]. Dostupno na: https://tinyurl.com/y2bet5y6.

Rosenbaum, L. Johns Hopkins changed its guidance on re-opening the economy after pushback from librarians. // Forbes. 2020. [citirano: 2021-01-16]. Dostupno na: https://www.forbes.com/sites/leahrosenbaum/2020/04/23/johns-hopkins-changed-its-guidance-on-re-opening-the-economy-after-pushback-from-librarian$\mathrm{s} /$ ? $\mathrm{sh}=35206 \mathrm{e} 7 \mathrm{~d} 71 \mathrm{a} 2$.

Slovenski jezik i kultura online. // YouTube. [citirano: 2021-01-18]. Dostupno na: https://www.youtube.com/watch?v=Dms9yuZiocA.

Sve naše zgrade. [citirano: 2021-01-18]. Dostupno na: https://tinyurl.com/y35h5hmb.

U 4 zida. // YouTube. [citirano: 2021-01-18]. Dostupno na: https://www.youtube.com/ watch?v=Uy-kRgAP-S0.

Uskršnja radionica: izrada čestitki. // YouTube. [citirano: 2021-01-18]. Dostupno na: https://www.youtube.com/watch?v=6Xxz5uOIxr4.

Virtualni književni susret s Ivanom Francišković Olrom. // YouTube. [citirano: 2020-0118]. Dostupno na: https://www.youtube.com/watch?v=zhGNZ-OBUxs.

Virtualnih četiri. // YouTube. [citirano: 2021-01-18]. Dostupno na: https://www.youtube.com/watch? $\mathrm{v}=$ kcgRRwcPdI. 


\title{
PRILOG 1
}

\begin{abstract}
ANKETNI UPITNIK
Ispitivanje zadovoljstva korisnika online uslugama i virtualnim programima Gradske knjižnice »Ivan Goran Kovačić« Karlovac
\end{abstract}

1. Spol

Muško

Žensko

2. Starosna dob

$18-25$

26-37

$38-48$

49-57

$58-70$

3. Jeste li član Gradske knjižnice „Ivan Goran Kovačić“ Karlovac?

$\mathrm{Da}$

$\mathrm{Ne}$

4. Koristim usluge (moguće je odabrati više odgovora)

Informativno-posudbenog odjela

Odjela za djecu i mladež

Odjela za djecu predškolskog uzrasta

Odjela audiovizualne građe

Zavičajnog odjela

Studijskog odjela

Bibliobusne službe

Knjižnice za mlade

Knjižnične stanice Švarča

Odjela slovenske knjige 
5. Upoznat/a sam s online uslugama koje nudi Gradska knjižnica „Ivan Goran Kovačić" Karlovac

Da

$\mathrm{Ne}$

6. Koristim (koristio/la sam) sljedeće online usluge (moguće je odabrati više odgovora) Upis i obnova članstva

Rezervacija knjiga

Plaćanje zakasnine (iznimni slučajevi)

E-iskaznica

E-knjiga

Platforma digitaliziranog karlovačkog tiska i baštine

Otvoreni pristup virtualnoj referentnoj zbirci

Društvene mreže (Facebook, Instagram, YouTube kanal)

7. Molimo, ocijenite zadovoljstvo postojećim online uslugama.

Uopće nisam zadovoljan

Donekle sam zadovoljan

Zadovoljan sam

U potpunosti sam zadovoljan

8. Kako ste saznali za online usluge koje knjižnica nudi? (moguće je odabrati više odgovora)

U knjižnici

Putem mrežne stranice knjižnice

Putem Facebook stranice knjižnice

Putem Instagrama

Putem YouTube kanala knjižnice

Putem medija

9. Koje online usluge biste željeli da knjižnica ima, a trenutno ne nudi?

10. Jeste li pratili virtualne programe knjižnice u 2020. godini?

$\mathrm{Da}$

$\mathrm{Ne}$ 
11. Koje ste programe pratili/pratite? (moguće je odabrati više odgovora)

Virtualni književni susreti s poznatim hrvatskim književnicima

E-izložbe

Virtualni edukativni zapis o korištenju e-knjige

Virtualni edukativni zapis o slovenskom jeziku i kulturi te platformi Biblos

Virtualne čitaonice za djecu

Virtualne radionice za djecu

Virtualna radionica za odrasle

Knjiška putovanja

Videozapisi čitateljskih klubova

Tečaj slovenskog jezika

12. Molimo, ocijenite zadovoljstvo virtualnim programima?

Uopće nisam zadovoljan

Donekle sam zadovoljan

Zadovoljan sam

U potpunosti sam zadovoljan

13. Kako ste saznali za virtualne programe? (moguće je odabrati više odgovora) U knjižnici

Putem web stranice knjižnice

Putem Facebooka

Putem Instagrama

Putem Youtube kanala knjižnice

Putem medija

14. Koje virtualne programe biste voljeli da knjižnica nudi u budućnosti?

15. Je li Vam draži osobni dolazak u knjižnicu ili online usluge i virtualno praćenje programa?

Osobni dolazak

Online/virtualne usluge 